Effective marginal and average tax rates in the 2017 Italian tax-benefit system

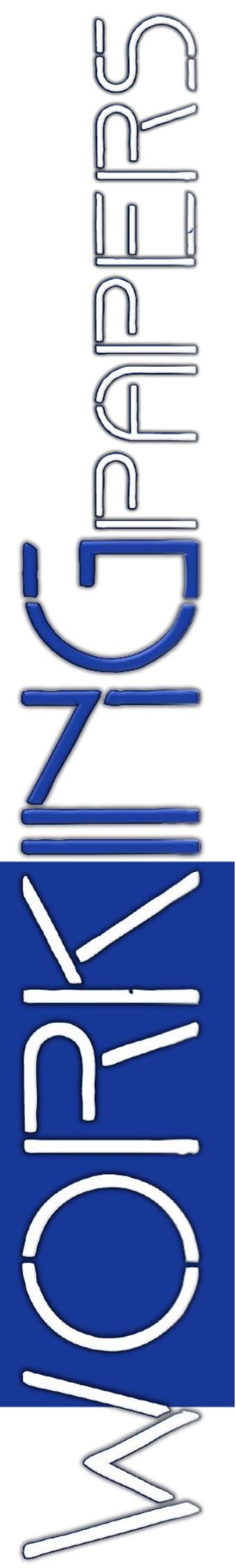

Fernando DI NICOLA, Melisso BOSCHI and Giorgio MONGELLI 
Opinions expressed in this paper are those of the author(s) and do not necessarily reflect views of the public administration of affiliation.

Le opinioni espresse dall'autore (dagli autori) non riflettono necessariamente quelle della pubblica amministrazione di cui fa parte.

DF Working Papers, 2017

MEF Ministero dell'Economia e delle Finanze

Dipartimento delle Finanze

Via dei Normanni, 5

00184 Roma

Email df.wpapers@ finanze.it

http://www.finanze.gov.it/

Scientific committee

Massimo Bordignon (Università Cattolica del Sacro Cuore di Milano)

Silvia Giannini (Università di Bologna)

Ernesto Longobardi (Università degli Studi di Bari “Aldo Moro”)

Giacomo Pignataro (Università degli Studi di Catania)

Antonio Felice Uricchio (Università degli Studi di Bari “Aldo Moro”)

Editorial board

Maria Teresa Monteduro (Dipartimento Finanze)

Fernando Di Nicola (Dipartimento Finanze)

Paolo Puglisi (Dipartimento Finanze)

ISSN electronic edition 2610-8887

Papers can be downloaded free of charge from the MEF website:

http://www.finanze.it/opencms/it/il-dipartimento/documentazione/Collana-di-lavori-edi-ricerca/ 


\title{
Effective marginal and average tax rates in the 2017 Italian tax-benefit system* $^{*}$
}

\author{
by \\ FERNANDO DI NICOLA', MELISSO BOSCHI ${ }^{*}$ and GIORGIO MONGELLI ${ }^{\S}$
}

\begin{abstract}
The personal income tax-benefit system influences, through marginal and average tax rates, income redistribution, labour supply, and tax evasion. In this paper we present, for the main taxpayer types and income levels the statutory and implicit marginal tax rates generated by the Italian personal income tax-benefit system components (social contributions, personal income tax, income type deductions, family-related deductions, family allowance, local surtaxes, and the "80 euro monthly bonus") along with the effective marginal tax rates deriving from their interaction. These tax rates are computed both for hypothetical taxpayer types (employee, retiree, self-employed with and without dependent family members) and using a microsimulation model based on a representative sample.

The results show that the Italian tax-benefit system generates a broad range of effective marginal tax rates, with positive and negative values, determining, in some cases, also "poverty traps" (that is a marginal tax rates higher than 100 percent). The marginal and average tax rates are also sometimes decreasing with growing taxable income, while at a low level of income we have such high tax rates that a disincentive for labour supply may result. With this evidence, a correction of the Italian tax-benefit system appears desirable both to preserve a more efficient income redistribution as well as labour supply incentives.
\end{abstract}

Keywords: Personal income tax, Effective marginal tax rates, Average tax rates, Income redistribution, Labour supply

JEL codes: $\mathrm{H} 21, \mathrm{H} 24, \mathrm{H} 31$

\footnotetext{
* We thank Michele Bernasconi, Francesco Forte, Francesca Zantomio, participants to the XXVIII Annual Congress of the Italian Society of Public Economics (SIEP 2016), and two anonymous referees for helpful comments on previous versions of this paper

${ }^{\dagger}$ Ministry of Economy and Finance, Department of Finance, Fernando.DiNicola@ finanze.it

${ }^{\ddagger}$ Senate of the Republic of Italy, Budget Committee Secretariat, Melisso.Boschi@ senato.it

$\S$ Ministry of Economy and Finance, Department of Finance, Giorgio.Mongelli@ finanze.it
} 


\section{Introduction}

In this paper we contribute to the analysis of the Italian tax-benefit system by presenting the measures, with their determinants, of the effective marginal ${ }^{1}$ tax rates on personal gross income, to highlight potential undesired consequences on labour supply, income redistribution, and tax compliance.

Under modern tax-benefit systems, an income increase is partially offset by the combination of taxes increase and benefits reduction. How much of an extra euro of income is offset by increased taxes or reduced benefits defines the effective marginal tax rate (EMTR). For a given gross income, differences across individuals and households conditions determine different EMTRs. A distinction may be made between explicit (statutory) versus implicit marginal tax rates: the first ones derive from tax rates and brackets established by personal income tax or social contribution rules; the second ones occur when a modification of tax credits, tax deductions, allowances, depending on income variations, generate de facto an increase or decrease of disposable income. When we observe a tax-benefit system, it is useful refer to both explicit and implicit marginal tax rates, combining them into global "effective" rates.

All else equal, EMTRs affect people's incentives to work - under higher rates people tend to work fewer hours since individuals' behavior depends on net as well as gross income. This behavioral response, in turn, might affect labour supply.

EMTRs may also affect income redistribution and tax compliance.

We compute EMTRs faced by taxpayers grouped according to individual and household conditions as well as income level. In analogy with the analysis on the US system periodically published by the US CBO (see Congressional Budget Office, 2012a, 2015) we take account of relevant factors that influence labour supply, tax compliance and income redistribution via the EMTR, such as social contributions, personal income tax (PIT), income type and family-related tax deductions, local surtaxes, family allowance, and the so called "80 euros monthly bonus". A growing interest in EMTRs computation is directly shown, among others, by the OECD (Caronte et al., 2004, Immervoll, 2004) and the New Zealand Treasury (McAlister et al., 2012), as well as by the tax reform design analysis².

\footnotetext{
${ }^{1}$ We also present, for completeness and comparison, the effective average tax rates (EATR).

${ }^{2}$ See, among others, Diamond (1998), Saez (2001), Piketty et al. (2013). For Italy see Baldini et al. (2017), Borri et al. (2014), De Vincenti and Paladini (2009), and Di Nicola and Paladini (2017).
} 
The Italian tax-benefit system, as many others, generates a number of marginal rates - the statutory tax rates, that is those determined by the tax code, and the implicit marginal tax rates, determined by tax deductions and benefits that change with income. Global EMTRs result from the combination of statutory and implicit rates, and give the change of disposable income caused by a change of gross income.

This paper is not meant to study the distributional effects of the Italian tax system - for a given redistribution due to the structure of average tax rates, and measurable through distributional indexes, different EMTRs can prevail. This paper is not meant to study the effects of EMTRs on work incentives, either - a different and complex methodology would be necessary, with more discretionary results.

We nonetheless provide a first account, with a description of the generating mechanisms, of the EMTRs resulting from the Italian tax-benefit system in 2017. To this aim, following CBO (2012b), we use two distinct approaches.

First, we focus on the change of both single and global EMTRs as income changes for some hypothetical taxpayers, defined by relevant income type and household composition. This methodology allows us to notice the separate and detailed effects played by the main single factors, thereby facilitating both a better knowledge and more efficient changes by policy makers.

As clearly noted by CBO (2012b), however, this approach has nothing to say about the marginal tax rates faced by actual households and the fraction of households that fall within each income range. To tackle this limitation, our second and complementary approach bases on microsimulation to obtain the distribution of effective marginal tax rates for a representative sample of actual taxpayers. In this way, we lose the single factor's role, but we observe for each observed subsample the global and actual marginal rate.

\section{The influence of effective marginal tax rates on labour supply, income redistribution, and tax compliance}

The structure of effective marginal tax rates is rather complex and scarcely perceived by Italian taxpayers, for which it is more palpable, instead, the whole tax liability determined by the average rate on one hand, and the statutory personal tax rates on the other hand. 
One may even doubt that the policymaker itself is fully aware of the effective rate structure of the system, given the large number and complexity of tax-benefit instruments, leave alone the huge amount of innovations regarding tax base, rates, brackets, deductions, and transfers that have stratified over time.

In this Section we briefly recall the likely effects that EMTRs may exert on labour supply, income redistribution, and tax compliance.

\subsection{Labour supply}

Market participants may be discouraged to increase their labour supply or productivity as they realize that a gross income increase may result in a far smaller improvement, if not an equivalence or a decrease, of disposable income. As we discuss below, this effect results from allowances and transfers as well as the interaction of taxes and social contributions.

EMTRs may influence working decisions in a number of different ways. For people having already a job, for example, EMTRs may affect the number of work hours, or the decision between part-time or full-time work; it may induce an employee to negotiate fringe benefits in place of a higher salary, or to take a second job. For people without a job, on the other hand, EMTRs can influence the decision on whether looking for a job or not. To sum up, high EMTRs discourage labour supply both in terms of entering in labour market as well as increasing worked hours. The design of an appropriate tax-benefit providing incentives to labour supply along with income redistribution, represents, therefore, a crucial factor to sustain economic productivity.

If and how much an increase in EMTR affects labour supply has been one of the most debated issues in Economics for decades. This effect results from two distinct factors having opposite sign. On one hand, an increase in taxes makes working relatively less attractive with respect to alternative uses of time - typically leisure, rest, self-production. On the other hand, increasing taxes stimulate people to work more that is a larger number of hours within the same job or taking a second job - in order to keep the same disposable income level and, therefore, the same amount of consumption and saving.

Which of these two factors will prevail in the real world remains a statistical question, and the answer may change across time and countries. 
In the USA, for example, there is some evidence (see Congressional Budget Office, 2012a, and McClelland and Mok, 2012) that an increase of EMTRs induces employed people to decrease the number of hours worked or productivity.

Moreover, effects change across different groups of people. On average, effects are larger for working age women with respect to men, although this difference has been weakening in recent years with women reacting less to EMTRs changes if family services are available (see Keane 2011). According to Meghir e Phillips (2010), in UK the combination of taxes and benefits affects both the decision to enter the job market as well as the number of worked hours. EMTRs are important for low as well as high level education males relative to the decision about entering the job market, while it is less important relative to the number of worked hours.

Similar results hold for Italy. Aaberge et al (2002) and Aaberge and Colombino (2006), in fact, find that the tax-benefit system affects women participation to the job market much more than men. This effect, moreover, is also pronounced for low per capita incomes within households.

Also individual versus family reference of tax-benefit measures can affect EMTR levels and effects. When, as in Italy for PIT (family tax deduction and 80 euro monthly bonus included) we have taxation and benefits based on individual income, EMTR for low income and often women are lower. If we have instead benefits assigned on the basis of a household income (as for Italian ANF family allowance and other transfers based on equivalent income) EMTR for the single taxpayer can be higher, if the spouse or another cohabitant have a high income.

\subsection{Income redistribution}

The effects of EMTR on labour supply are important for income redistribution, too. High rates may end locking people in low income states, while sometimes rates over 100 percent determine the so called "poverty traps".

For an income tax system to be progressive, the average tax rate should increase with income. Increasing effective marginal tax rates are crucial to obtain increasing average rates, as these can be also calculated as a weighted mean of marginal rates.

A second desired target for "vertical fairness" is the application - ceteris paribus - of higher or not decreasing EMTRs to increasing income brackets; furthermore, for an 
evaluation of the redistribution policy through marginal tax rates, statutory rates and brackets are important, but not the only factor influencing results.

As we show below, in the Italian tax-benefit system not only effective marginal but also average tax rates sometimes decrease over certain income levels, stressing some of the Italian system problems.

Also the relation between globalization and low income trends can be influenced by average and marginal tax rates. Milanovic (2016) underlines that globalization is determining a reduction of executive workers incomes; the tax wedge can contribute to reduce the decline of net incomes and labour supply, reducing the increase of inequalities.

\subsection{Tax compliance}

We may advance the sensible assumption that the relationship between EMTRs and tax compliance is twofold. On one hand, in fact, large and erratic EMTRs can stimulate workers within certain income brackets to avoid taxes through outright black work or mere tax incompliance. On the other hand, due to tax evasion, computed EMTRs only partially reflect true rates. Tax incompliance in Italy is estimated to be large - about 200 billions of tax base and about half of taxes - and concentrated in around half of the overall taxpayers number.

In particular, estimates of tax base evasion are included in a range between 23 and 55 percent of total depending on the methodology used (see Marino and Zizza, 2012, for a review). Most studies agree on a lower tax evasion for employed work with respect to self-employed and firms. Employed work tax base evasion range between 0 and 9 percent across studies, while for self-employed the same figure ranges between 28 and 68 percent. As for the tax revenue evasion, estimates indicate 13 percent for employed work and 69 percent for self-employed. This result in a proportion of tax base evasion ranging between 10 and 15 percent of Italy's GDP.

Notwithstanding the large amount of tax evasion in Italy, scarcity of academic research was paired by a lack of official estimates. One notable exception was given by the "Rapporto sull'evasione fiscale" published by the Ministry of Economy and Finance in 2014, according to which Italy's tax gap - the difference between tax owed and tax paid - amounts to 45 of billions euro for personal and corporate income tax over the 
period 2001-2006, while it is estimated to be around 44 of billions euro over 2007-2012. The Department of finance and the Tax Agency, moreover, frequently estimate tax evasion figures although their results remain often unpublished.

In recent years there are two important innovations. The Government publishes, on the basis of a specific Commission's work, an annual report (MEF, 2017) about amounts and strategies related to tax evasion and not observed economy. ISTAT - the Institute for National Accounts - presents (2017) similar consistent estimates in an annual report.

\section{The Italian tax-benefit system for individuals and households in 2017}

Before illustrating the effective marginal tax rates structure, we briefly describe the main factors that determine it within the Italian tax-benefit system for 2017.

Social contributions on wages are the first quantitatively relevant tax category. If we abstract from some low contribution rates meant to finance social security in some specific economic sectors and firm sizes, the standard compulsory social contributions rate is 9.2 percent of gross salary, which increases to 10.2 percent for salaries beyond 46,000 euro per annum. The social security contribution cancels out for gross salaries beyond about 100,000 euro, for people starting working after 1995 .

For term-contract workers enrolled on the National Institute of Social Security (INPS the Italian acronym) special fund, the social contributions rate is 10.9 percent, which decreases to 8 percent for retirees or workers enrolled on alternative funds. An income ceiling of about 100,000 euro is in place, while no floor exists.

The social contribution rate on artisans' and shopkeepers' income amounts to 23.55 percent, with a taxable income floor of 15,548 euro - which implies a much higher rate on declared income - and a ceiling slightly lower than 77,000 euro for taxpayers enrolled before 1996 and equal to 100,000 euro for those enrolled after this year. An additional one point rate is due between 46,123 and the ceiling.

Freelance professionals' income is subject to contribution rates that differ according to the professional associations' insurance fund. If, instead, their contributions flow to INPS, the rate amounts to 27 percent.

An additional consideration is about the underlying nature of social contribution, a sort of deferred remuneration, in the form of pensions as well as social benefits; in this 
context, the nature and the consequences of social contributions are irrelevant, because we want to consider the effects of social contributions in terms of EMTRs.

Once social contributions and other minor deductions from taxable income are subtracted, statutory personal income tax rates are applied to residual income.

The statutory personal income tax rates and taxable income brackets are as follows:

\begin{tabular}{cc}
\hline Tax brackets & Tax rates \\
\hline \hline up to 15.000 euro & $23 \%$ \\
over 15.000 up to 28.000 euro & $27 \%$ \\
over 28.000 up to 55.000 euro & $38 \%$ \\
over 55.000 up to 75.000 euro & $41 \%$ \\
over 75.000 euro & $43 \%$ \\
\hline
\end{tabular}

Examining PIT is important to underline the relevance of tax base definition in determining EMTRs; tax erosion reduced PIT base in the last decades: real estate notional or effective income, productivity benefits, minimum self-employed incomes and other categories were removed from PIT tax base and burdened with substitutive, reduced and proportional taxation. As a consequence, increasing that type of income (within eventual thresholds) do not generate any EMTR.

The most applied implicit rate derives from the decreasing tax deductions associated to different types of income: employee, retiree, self-employed. For employees, tax deduction amounts to 1.880 euro for incomes below 8,150 euro $^{3}$, and decreases beyond that threshold: rapidly up to 28,000 euro income (with an added rate around 4.5 percent), and more slowly beyond, until it vanishes at 55,000 euro income (thus determining an implicit rate of 3.6 percent). Beyond 55,000 euro income, tax deduction as well as the added implicit rate becomes null. This dynamic produces one of the undesired effects, since the EMTR for incomes between 38,000 and 55,000 euro results to be slightly larger than the 41 percent statutory rate applied to higher incomes ${ }^{4}$.

\footnotetext{
${ }^{3}$ Therefore, no tax is due for incomes below 8,150 euro, or higher income if other deductions apply.

${ }^{4}$ Higher incomes however are often subject to a larger average rate, thus preserving progressivity and the distributional role of PIT.
} 
For retirees, in 2017 a reformed structure of tax deductions is in place. Deductions are not differentiated anymore for taxpayers younger or older than 75 and are now decreasing with income, according to a calculation formula that differ depending on whether income exceeds or not the 15,000 euro threshold. As an effect, implicit rates of 8 percent apply above 8,000 euro income, 3 percent from 15,001 to 55,000 euro income, and null beyond 55,000 euro. This reform has produced the paradox that the second personal income EMTR (30.2 percent), once tax credits are taken into account, becomes one percent point smaller than the first one (31.3 percent).

With regard to self-employed taxpayers (small firms and freelance professionals subject to simplified accounting rules and not subject to substitutive taxation), the implicit rate deriving from decreasing tax deductions is simpler and less relevant: it amounts to 2.2 percent for incomes between the exemption threshold and 4,800 euro per year (which corresponds to 1,140 euro tax deduction) and it decreases smoothly until it vanishes for incomes above 55,000 euro.

One more implicit marginal tax rate derives from decreasing family-related deductions, applying to personal income tax payers with children or other dependent family members - that is family members whose annual income is less than the 2,841 euro threshold. This type of tax deduction depends on family member type (spouse, child, or other), on child age (up to or higher than 3), on child disability, on the number of children (more than 3 or not), and on income level. Decreasing family-related tax deductions apply to very large income brackets and may generate, depending on the conditions listed above, additional tax rates included between 1 and 3.5 percentage points 5 .

Regarding family financial support, an implicit rate also derives from the family allowance (ANF the Italian acronym), which applies to households - defined in different terms with respect to the taxpayer ones - whose earnings from employed work amounts to at least 70 percent of overall income. The employer's contribution to the allowance amounts to 0.68 percent for the private sector. This non taxable allowance is determined according to parameters depending on type and number of family members

\footnotetext{
${ }^{5}$ Notice however that these rates turn out sometimes to be null since largest deductions apply to low-level households, whose due tax are insufficient to allow for tax deductions. These households are thus unable to actually receive the "due" allowance.
} 
and income level ${ }^{6}$. The overall household income is computed including also non PIT taxable items, such as financial earnings. Income brackets are annually revised by INPS basing on cost of living changes. The family allowance decreases as income increases, given a certain family structure. From this derive supplemental tax rates that are extremely erratic and mainly included between 0.5 and 15 percentage points and more.

One further source of changing EMTR consists of personal income local PIT surtax levied by regional and municipal authorities. Within certain limits - set by national Government on income brackets and rate levels - the about 8,000 municipalities and 20 regional authorities have widely differentiated personal income surtax rates. Some authorities, for example, have introduced a specific progressivity typology by which rates increases apply to overall income instead of the corresponding bracket excess. Within a limited range, this determine another little "poverty trap" paradox, by which an increased gross income results in a lower net, disposable income.

The main rate leap, however, takes place at low income level as a consequence of the local additional tax rate vanishing if net PIT becomes null. This in fact implies that trespassing by only one euro the exemption threshold, the taxpayer has to pay an additional local tax levied on his overall income, not only on the exceeding income. The tax rate is thus larger than 100 percent. Aside these specific income ranges with very high rates, the marginal local tax rate is included between 1 and 3.5 percentage points.

As a last and relevant source of implicit marginal rates, we consider the $\mathbf{8 0}$ euro monthly bonus, introduced by the Italian Government in 2014 and at full speed since 2015. It consists of a monthly fixed amount allowance of 80 euro paid to employee and related workers whose overall income is included between the personal income tax exemption threshold (net of employment tax deduction) - corresponding to 8,150 euro and a maximum income of 24,000 euro per year. Beyond this level, the allowance decreases rapidly and linearly until it cancels out at 26,000 euro income.

Both the benefit access income threshold and the income range for decreasing allowance determine marginal rates that are very large and oppositely signed. As income oversteps the exemption threshold and the employee receives the bonus amounting to 960 euro per annum - the EMTR is negative (that is a marginal benefit) and larger than 100 percent: if gross income increases by 100, net income increases by

\footnotetext{
${ }^{6}$ This procedure identifies, de facto, per capita income on a family basis.
} 
over 1000 euro. Conversely, between 24,000 and 26,000 euro income per year, the bonus rapidly decreases and becomes null, so that the specific implicit rate is 48 percent. As we see below, in this income range the sum of statutory and implicit marginal tax rates produce an EMTR close to 100 percent $^{7}$.

The factors here considered, though not exhaustive, determine the largest part of effective marginal and average personal income tax rates variability.

\section{Effective marginal tax rates by income and household typology}

Having summarily described the Italian personal income tax-benefit system, from which a variety of marginal tax rates derive, we now proceed to present, graphically, effective marginal tax rates calculated according to the following two criteria.

First, in this section we present, by income level, the statutory personal income tax rates, the implicit rates resulting from the main components of the Italian tax-benefit system described above - social contributions, income type-related deductions, familyrelated deductions, local personal $\operatorname{surtax}^{8}, 80$ euro monthly bonus, family allowance - as well as the effective marginal tax rate resulting from their interaction.

We do this for a number of hypothetical households and taxpayers, deemed relevant according to income and family type, frequency, relevance of tax-benefit rules. For each case, moreover, we present a second graph that reports solely effective marginal vs average tax rates, since the former are relevant for both labour supply and tax compliance, while the latter are most important to gauge the progressivity and distributional features of a tax-benefit system.

Second, in section 5 we present, basing on results of a tax-benefit microsimulation model of the Department of Finance of the Italian Ministry of Economy and Finance, the distribution of EMTRs for a representative sample of taxpayers, reporting both the maximum-minimum intervals as well as the mean of the distribution for each income range. This exercise proves to be useful to understand the interaction of taxes and benefits rules, taking into account the actual frequency that benefits apply to different income level taxpayers.

\footnotetext{
${ }^{7}$ More specifically, 82 per cent for a single employee and 96 per cent for an employee with dependent spouse and two children.

${ }^{8}$ Here referred to a taxpayer resident in Rome, the greatest Italian city.
} 
The maximum-minimum intervals and mean EMTRs of the distribution for each income range give an additional, useful information since the microsimulation model, by taking into account almost all individual and family components that contribute to determine the effective marginal tax rate, generate a large number of rates for each income level. The interval and mean rates, therefore, help to summarize this information.

\subsection{Employee with dependent spouse and two children}

Figure 1 reports, for one of the commonest taxpayer type - employee with dependent spouse and two children - and for each income level, the marginal tax rate generated by each component illustrated above, along with the global EMTR (with a thicker line) resulting from their interaction.

To improve readability, social contributions, income type-related deductions, family-related deductions, local surtax, and family allowances rates are reported on the left hand side axes, while statutory personal income tax, 80 euro monthly bonus, and global EMTRs are reported on the right hand side axes.

It results clear that the Italian system high fragmentation produces a number of paradoxes. In particular, notice that:

1. family-related deductions implicit rates show several leaps, as a consequence of some additional tax deductions for the spouse, first upwards and then downwards, over a narrow income range;

2. between 15,000 and 38,000 euro of household income levels, implicit rates from ANF allowance present a larger than 10 percent points spike;

3. by converse, the ANF allowance for a new employee (for this household type over 3,000 euro per year) produces a large negative implicit rate (benefit) above the null income level;

4. the social contributions rate vanishes above the income ceiling just above 100,000 euro;

5. the 80 euro monthly bonus determine two spikes, one negative and one positive, the first above the exemption income level and the second when the bonus decreases within the 24,000-26,000 income range. 


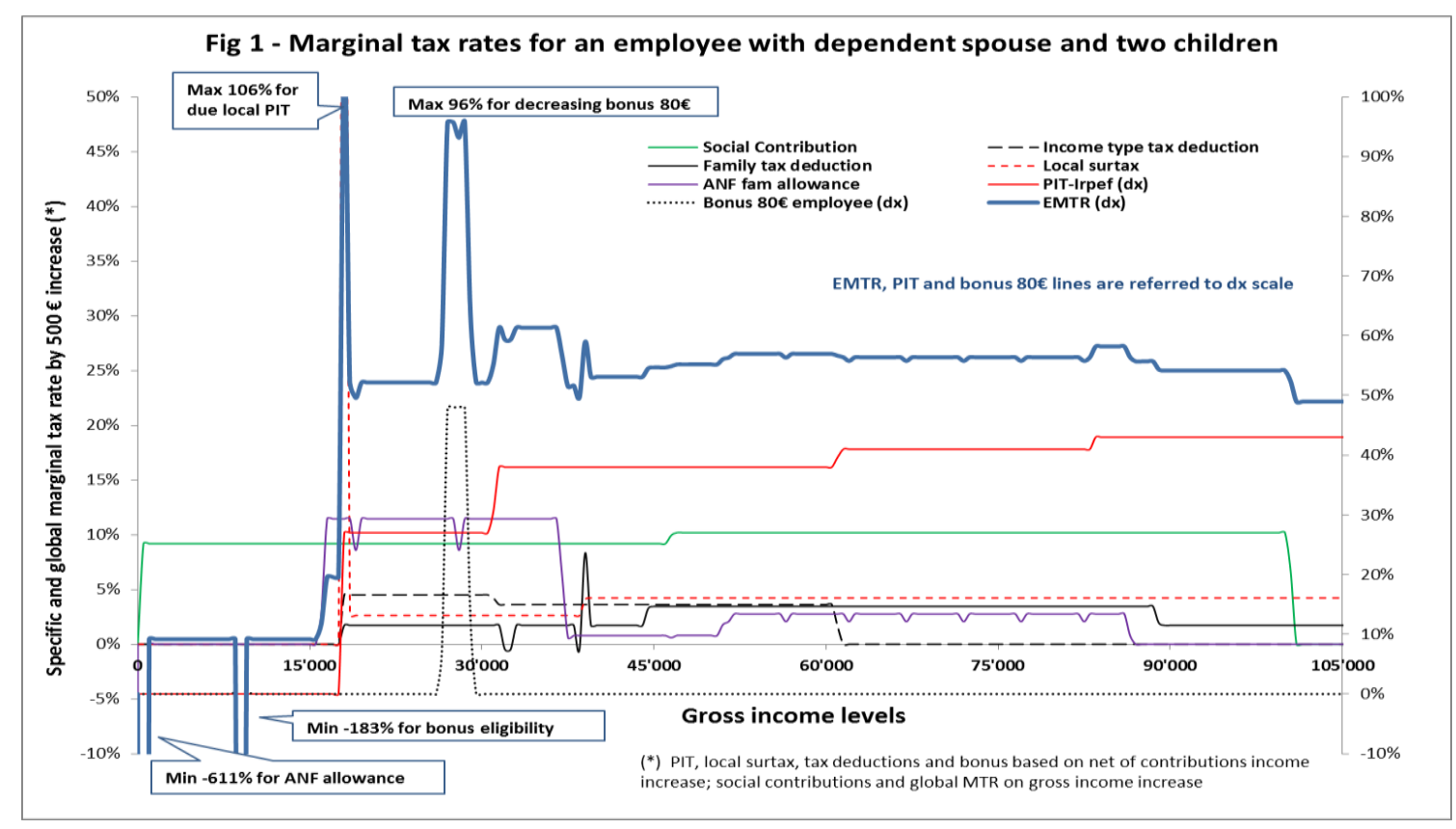

If we look at EMTR, whose values are reported on the right hand side scale in percentage points, some features stand out:

1. the large negative rates faced by the low income level taxpayer;

2. the high rates determined by the beginning application of local surtaxes (beyond the PIT exemption income level) and the decrease of 80 euro monthly bonus (above 24,000 euro income level net of contributions);

3. the slight decrease for income levels above 100,000 with respect to all income levels above 20,000 .

The comparison of effective marginal and average rates, illustrated by Figure 1b, confirms that the Italian tax-benefit system does not appear to be framed within a general design.

Notice, in fact, that, as the income level crosses the tax exemption threshold, the taxpayer gains right to a 960 euro allowance that determines, along with a strongly negative EMTR, a reduction of the average rate too. This appears to be an undesirable effect of the system because it implies a regressive redistribution in a certain income range.

Two more rate leaps take place, as already noted as a comment to Figure 1: as income crosses the tax exemption threshold of 8,150 euro, due to the application of local surtax, and as the 80 euro monthly bonus declines between 24,000 and 26,000 
income levels. These sharp changes of EMTRs correspond to a rising average rate curve slope.

The remaining changes of EMTRs, which do not affect significantly average rates, derive from changes of social contributions and family tax deductions.

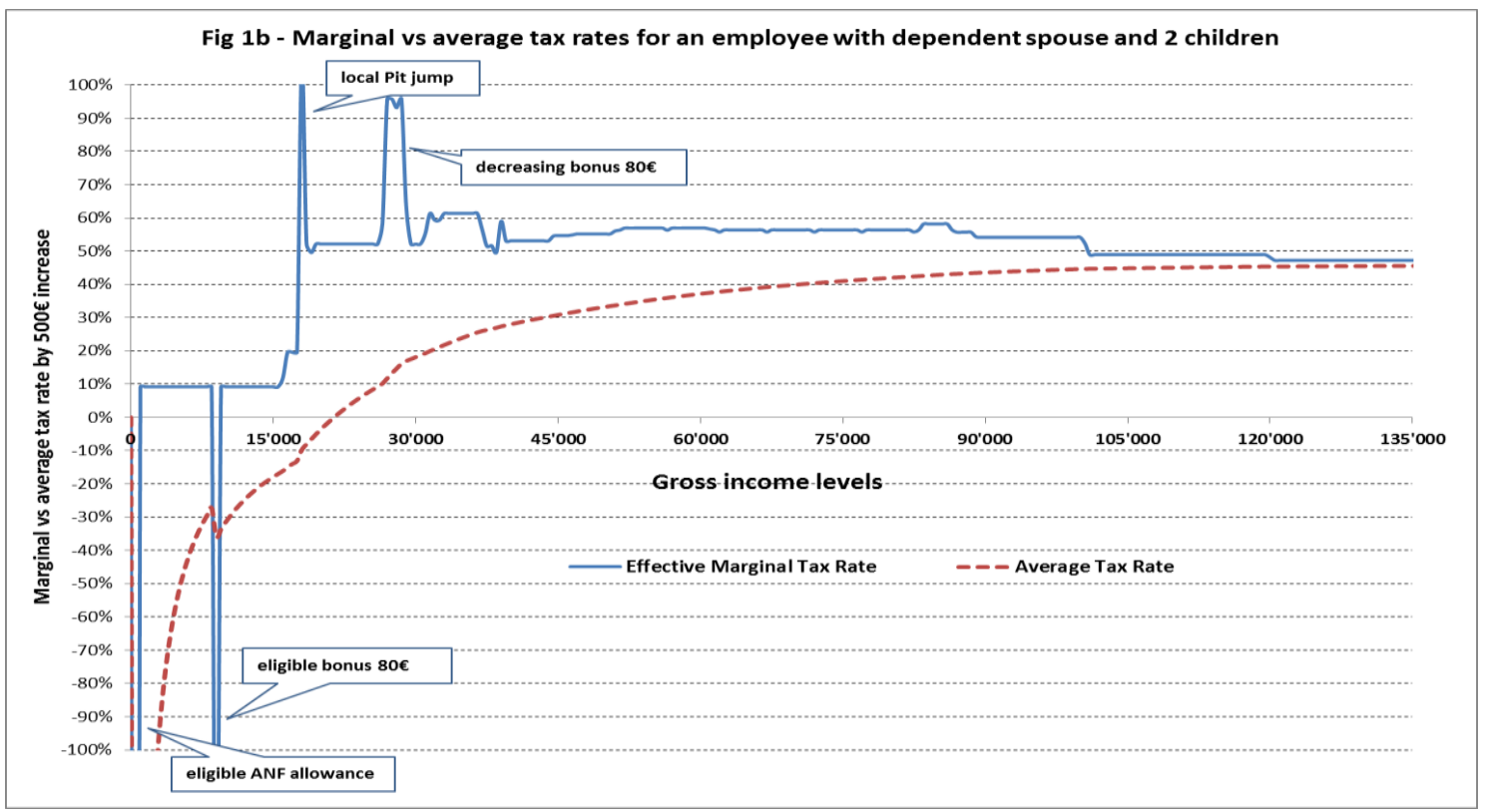

\subsection{Employee without dependent family members}

Figure 2 reports implicit rates and EMTRs for a different hypothetical taxpayer an employee worker without dependent family members, therefore without family allowances and deductions.

Although in this case the rates structure appears to be simpler, two hikes persist the first one, amounting to slightly less than 50 percent, is determined by the local surtaxes application, while the second one, amounting to a specific 48 percent, derives from the mentioned decreasing 80 euro monthly bonus. 


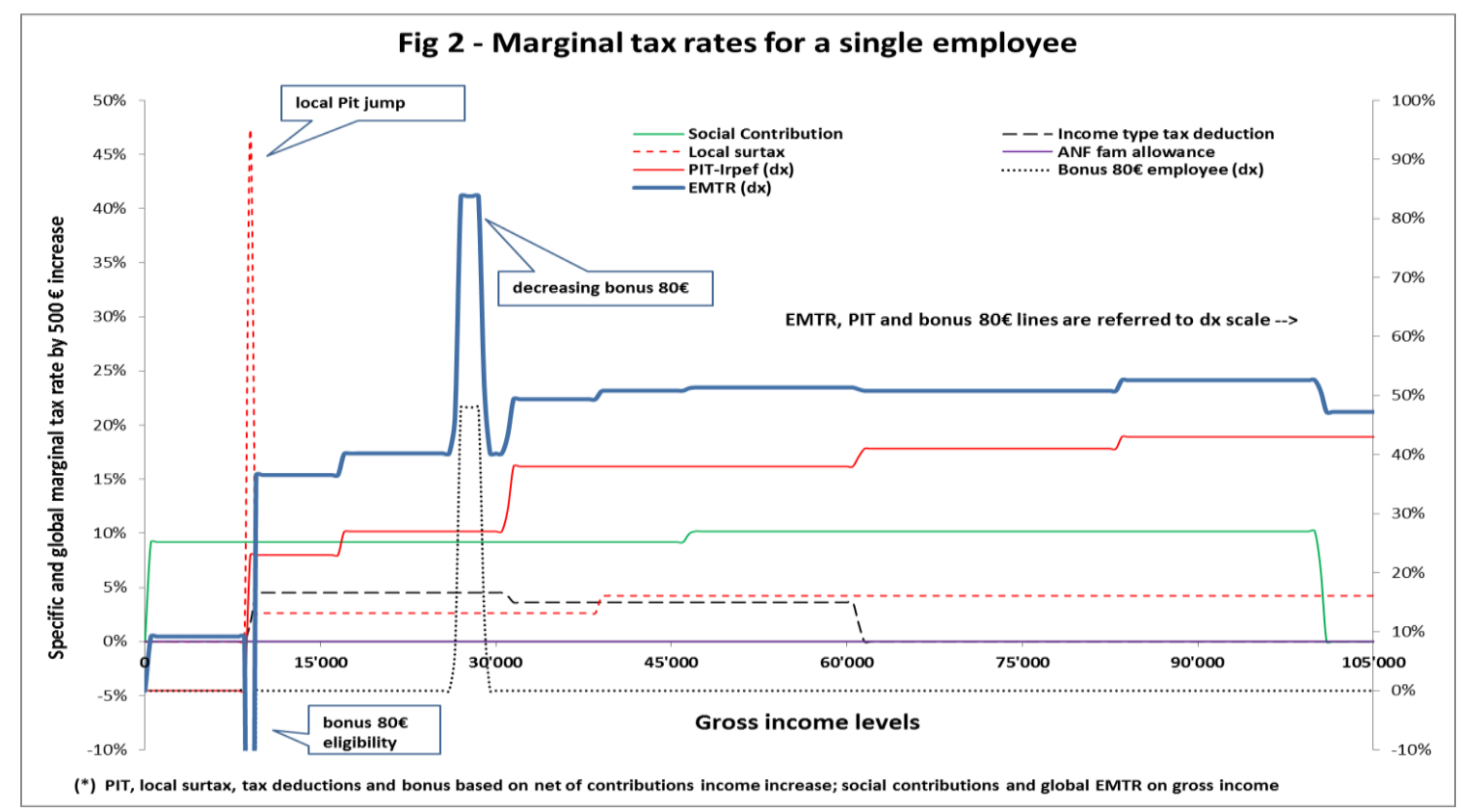

The EMTRs for this hypothetical taxpayer, like the previous one, lowers slightly above 100,000 euro with respect to income included between 26,000 and 100,000, range in which the effective rate remains almost unchanged.

Figure $2 b$ reports effective marginal and average tax rates for each income bracket.

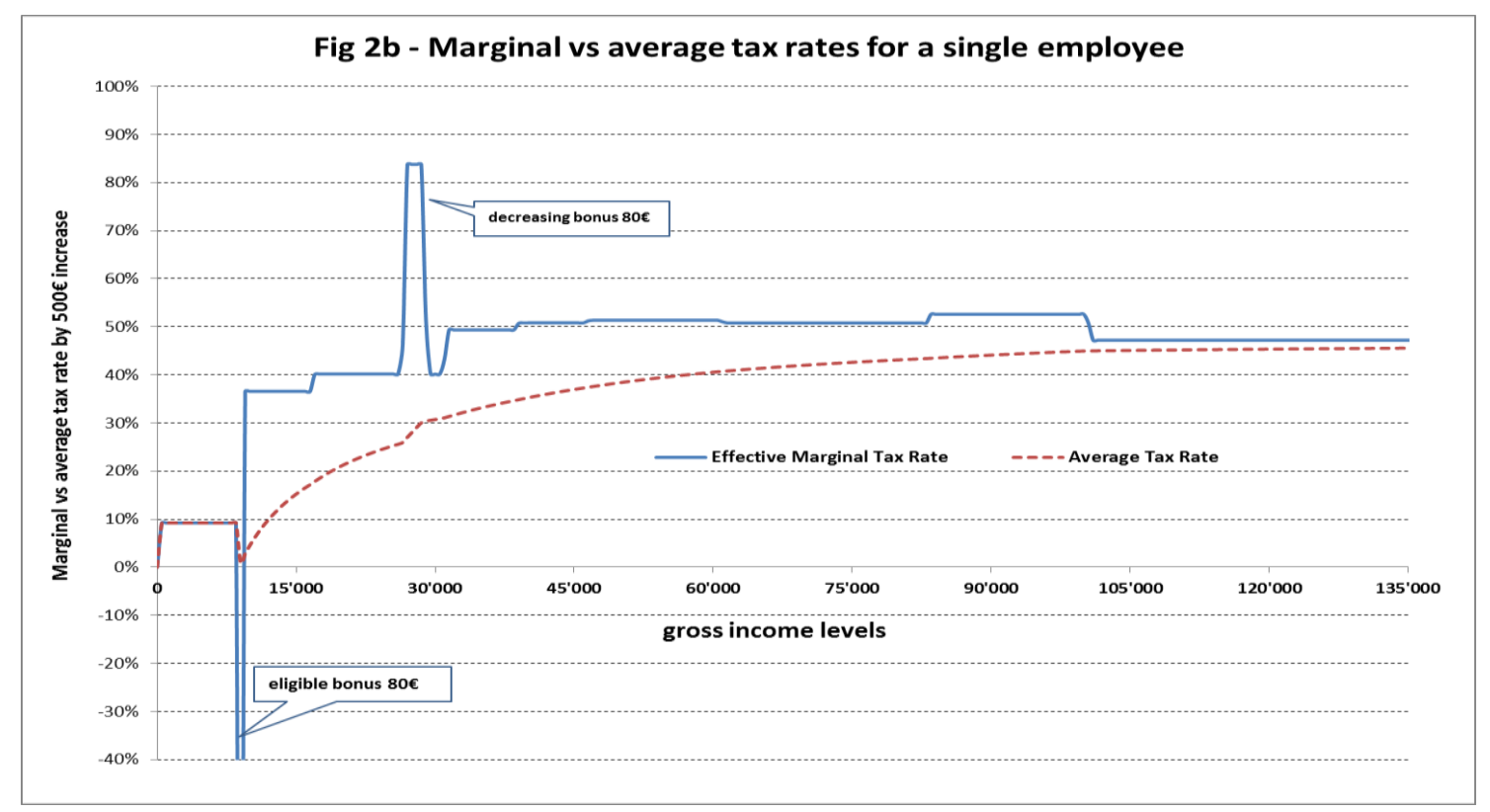

For this typology of taxpayer, as for the previous one, the average tax rate decreases beyond the non taxable income threshold as a result of the 80 euro monthly bonus application mechanism. 


\subsection{Retiree without dependent family members}

As it results evident from Figure 3, the structure of implicit rates for a retiree without dependent family members is much simplified by the absence of social contributions and 80 euro monthly bonus, as well as family-related deductions and allowances. The only relevant remaining hike corresponds to the tax exemption income threshold, as the local surtaxes start to be applied to the entire income.

Notice that the statutory personal income tax rate increase from 23 to 27 percent at the 15,000 euro income level is entirely balanced by the implicit marginal tax rate for pension deductions below the 15,000: the EMTR remains therefore about constant at 30 percent from 15,000 to 28,000 euro of taxable income, above which the statutory rate becomes 38 percent.

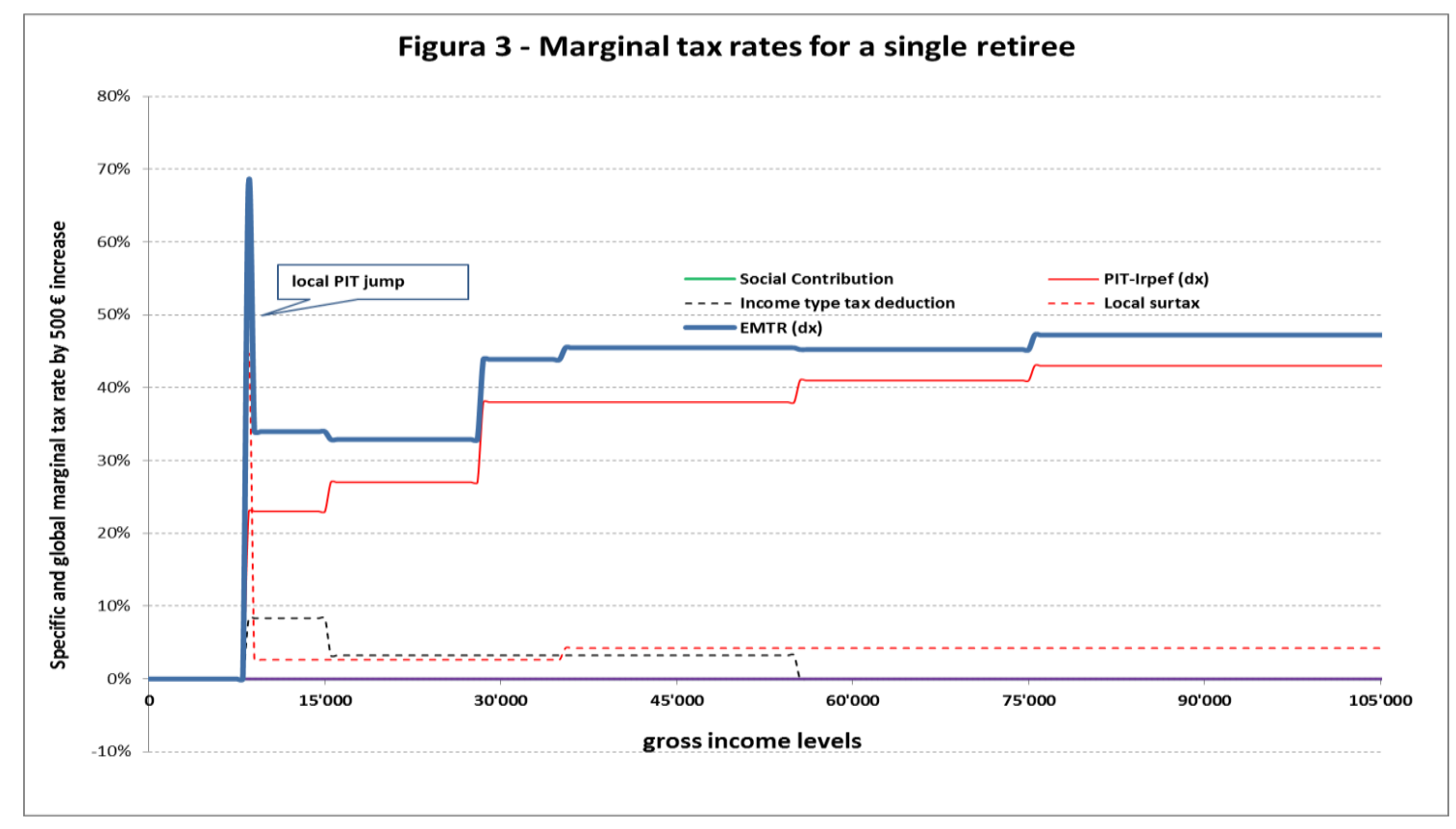

For the retired taxpayer, as shown in Figure $3 b$, the average tax rate never decreases, although the corresponding curve shows an increasing slope as the statutory personal income tax rate changes from 27 to 38 percent. 


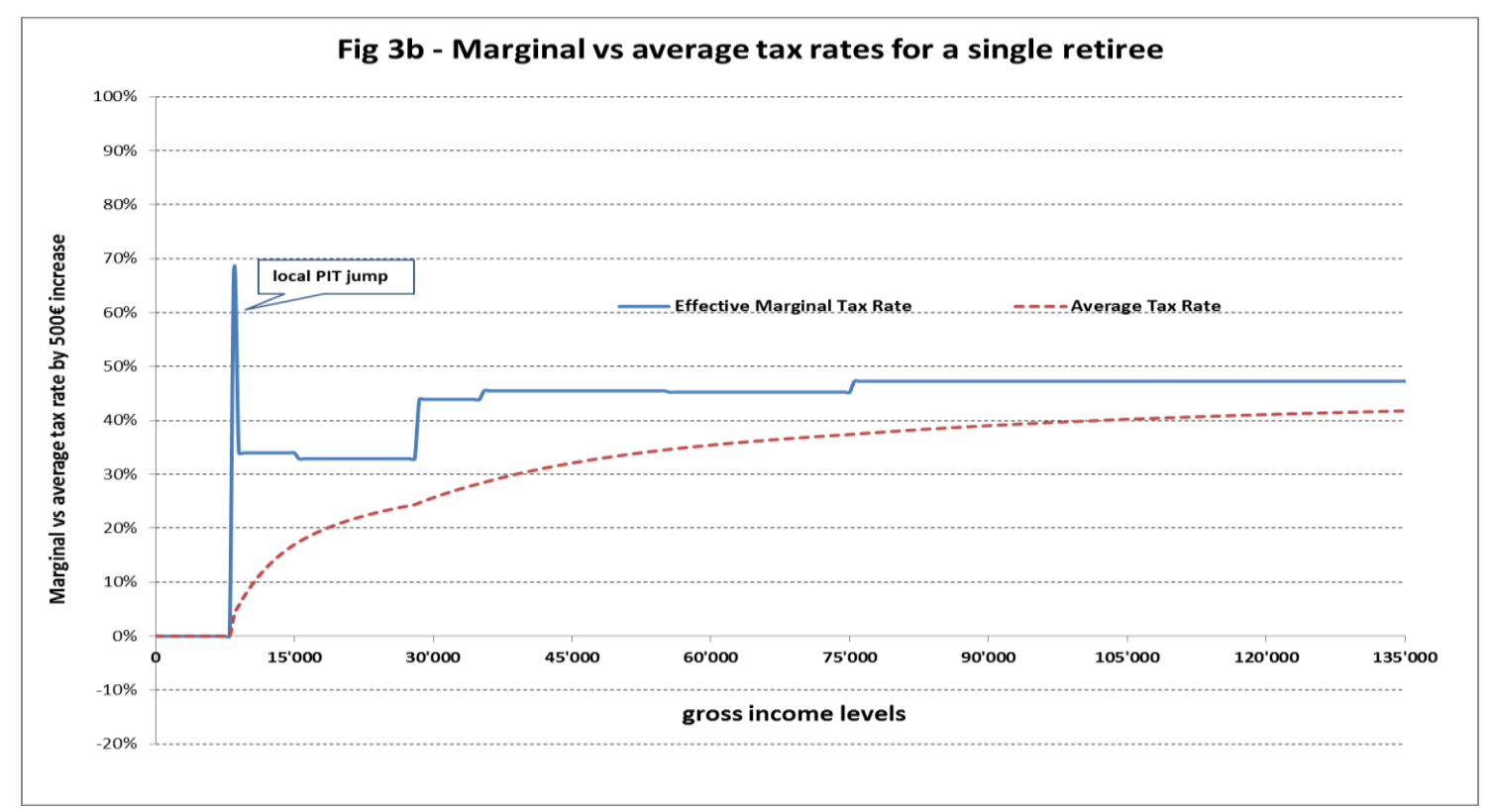

\subsection{Self-employed (shopkeeper) with dependent spouse and two children}

As a last hypothetical taxpayer we consider the case of a self-employed, specifically a shopkeeper, with dependent spouse and two children. Figure 4 reports the implicit rate for each tax and benefit category.

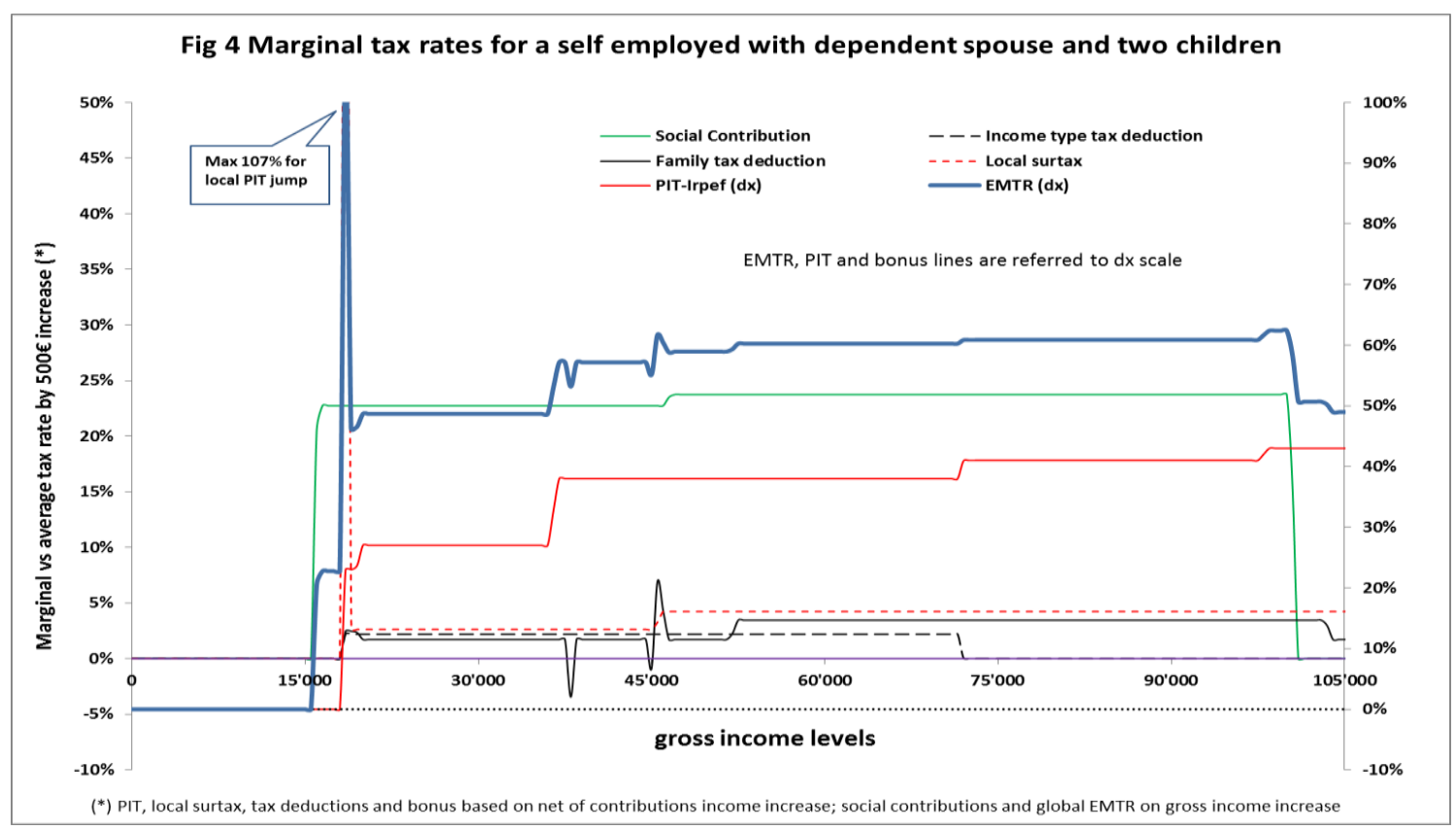

In this case, no implicit rate hike derives as income oversteps the exemption threshold since the corresponding tax deduction, compared to the employee case, is lower in level and linearly decreasing until it vanishes. 
The two relevant hikes remaining are common to the employee case, since they derive from the application of the local surtax and the social contribution ceiling.

Figure $4 \mathrm{~b}$ highlights a huge average rate hike corresponding to the application of a minimum social contribution (about 3,700 euro for shopkeepers and artisans) to low income self-employed. This minimum contribution is computed on a 15,500 euro notional income, which is annually revised to take account of inflation. Although rationalized as a way to take into account low tax compliance within self-employed taxpayers coupled with the need to finance an adequate pension level, the minimum social contribution generates huge rates since are applied also to near zero income levels.

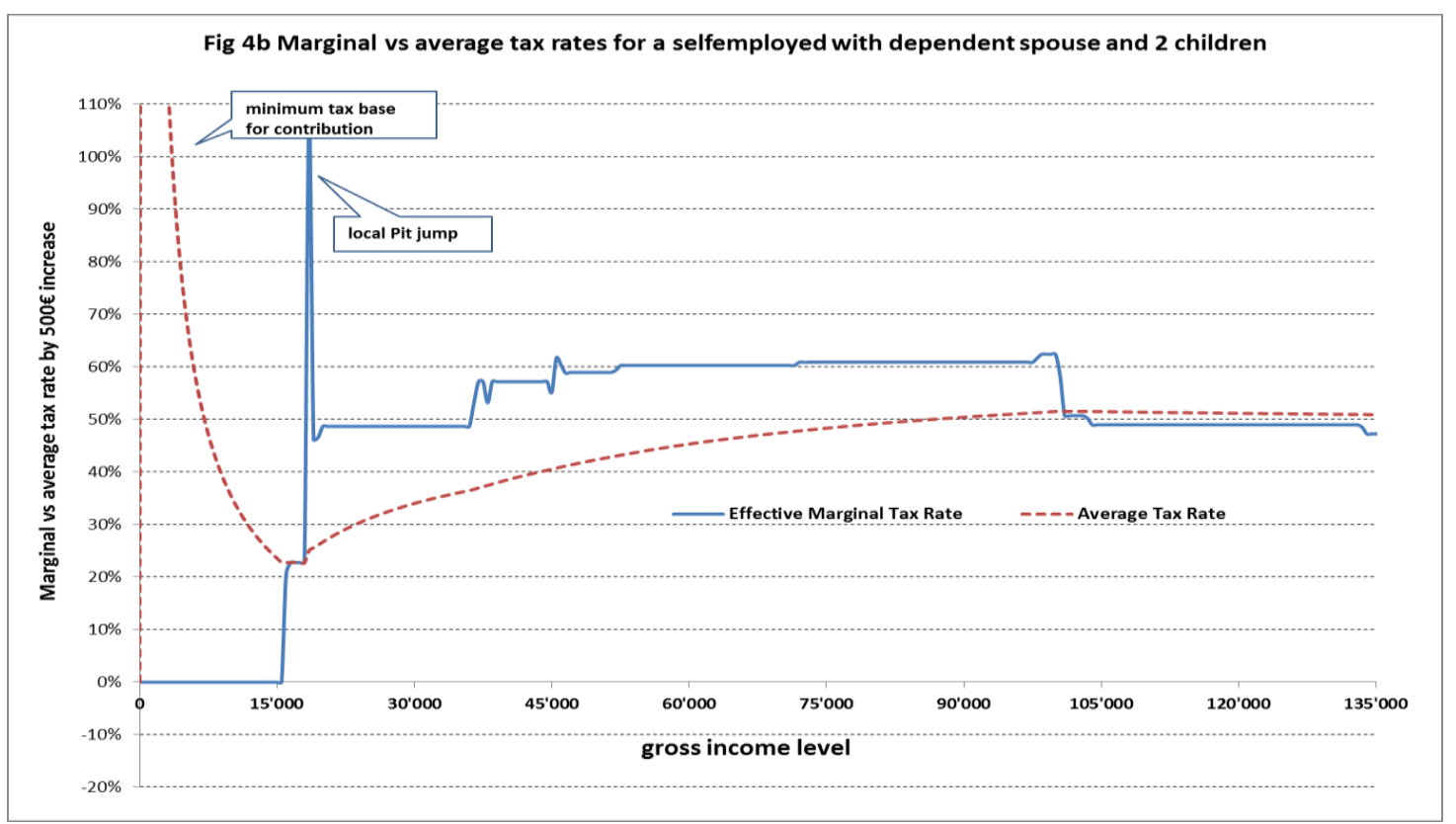

Notice that for the self-employed case the social contributions are owed without subdivision between employer and employee, so that, all else given, they are larger than those considered in the employee case, for which the employer contributions do not enter the analysis 9 .

\section{The marginal tax rate distribution for actual Italian taxpayers}

In the previous Section we recovered effective marginal and average tax rates on personal income separately for each of the main typologies of Italian taxpayer -

\footnotetext{
${ }^{9}$ If we considered the employer contributions too, we would obtain the cost of employee labour rather than gross income.
} 
employee with or without dependent family members, retiree, and self-employed. In this way we focused the attention on the single rules generating the various EMTRs.

By contrast, in this Section we compute the EMTRs by applying the microsimulation model developed at the Department of Finance of the Italian Ministry of Economy and Finance to a representative sample of Italian taxpayers ${ }^{10}$. This way of computing effective rates allows for a full accounting of actual effects of the tax-benefit system on real world taxpayers, although it makes less clear the connections with single rules generating the global EMTR.

We first derived the EMTR for each taxpayer in the sample and then we generated the distribution of such rates across deciles of increasing taxpayers' income levels ${ }^{11}$.

By analysing a real world sample of taxpayers, other factors determining EMTRs are brought to bear. Consider, for example, the common condition of mixed family earnings - from employee and self-employed work - the former slightly crossing the 70 per cent fraction required to be eligible for family allowance. As the latter just oversteps the 30 percent fraction of total income, the household loses the entire family allowance, so that the observed EMTR takes a jump. To take into account this further source of rates variation, we computed for each income tenth the range of rate dispersion (maximum and minimum) around its mean level.

\footnotetext{
${ }^{10}$ The model underlying logic, structure details, and main results are illustrated by Di Nicola et al. (2015). The model version applied in this paper uses a structure of taxpayers, tax benefit rules and income levels referred to 2017, as a calibration of Italian National Institute of Statistics' survey about 2013 incomes and 2014 living conditions (Istat EUSILC). All appropriate local surtax tax rates and brackets were applied.

${ }^{11}$ Gross income is here computed including notional house rents and social contributions due by employee.
} 


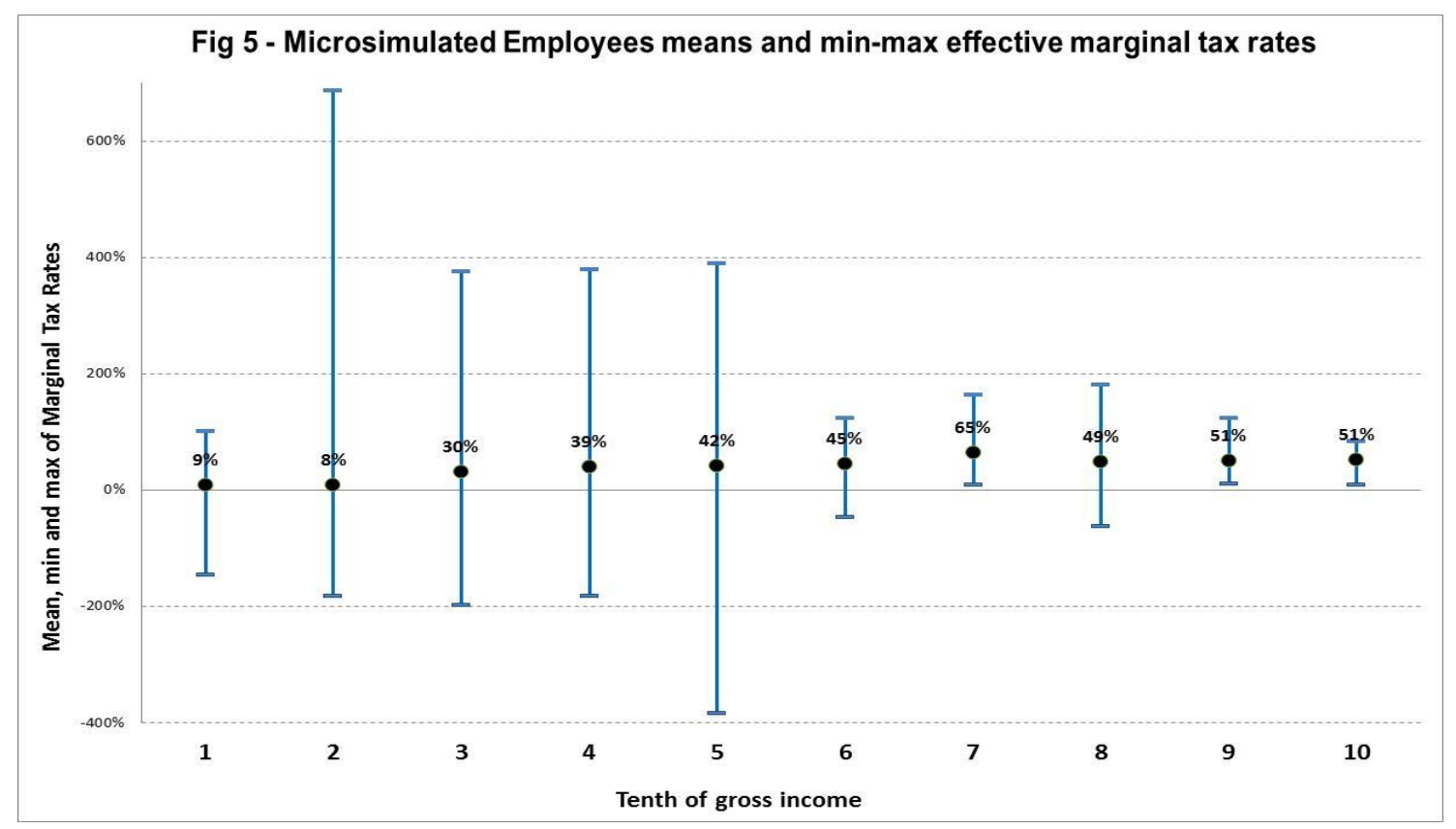

Results are reported in Figures 5, 6, and 7, each corresponding to one of the main taxpayers type: employee, retiree, and self-employed.

We can observe at first a not uniformly growing mean of EMTR when income increases: in the seventh tenth, in particular, we have a top EMTR at 65 per cent. This is mainly the effect of the decreasing monthly bonus 80 euro, with its 48 per cent implicit rate, given an average of internal income of about 25.000 euro.

Figure 5 shows a large EMTR variability from the second to the fifth tenth of gross income. Low EMTR values are due to the application of benefits such as the beginning of 80 euro monthly bonus or the whole ANF allowance when 70 per cent of employee income is passed. High EMTRs, on the contrary, are generated when a taxpayer with several tax deductions begins to pay PIT and, with it, local surtax calculated on the whole income. But also the loss of allowance (maternity, poverty and so on) can generate high implicit marginal rates. That is why these high marginal rates are concentrated in intermediate tenths.

Figures 6 shows that retired people EMTRs are more dispersed around their mean in the third and sixth tenth, in particular for the presence of very low marginal rates. 


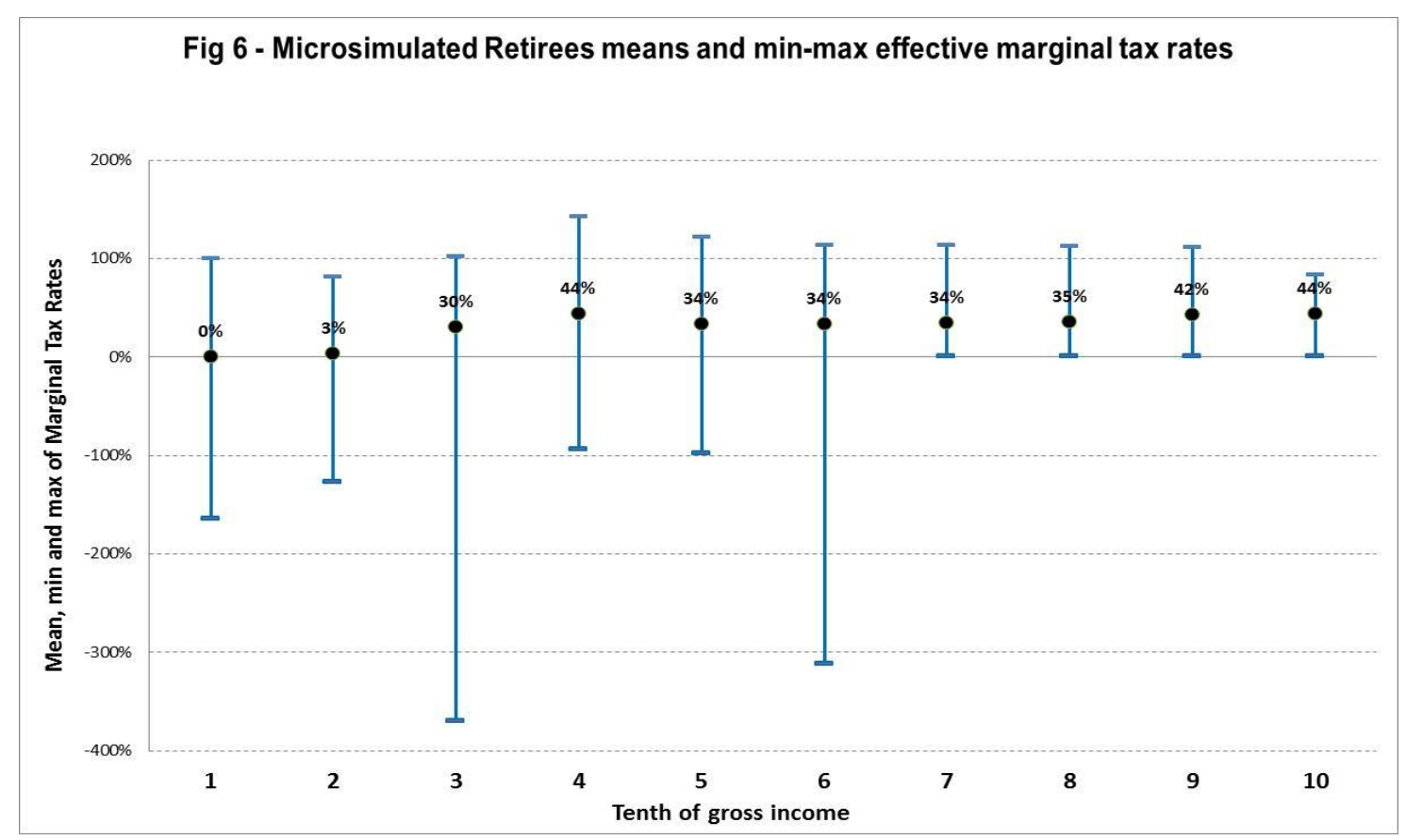

To explain high rates we can mention local surtax calculated on the whole income as PIT become to be due, as well as the partial loss of the so called "quattordicesima", a sort of bonus for retirees with incomes lower than certain thresholds.

The very low rates are essentially due to the whole ANF allowance when (rarely) the share of income from pension exceeds 70 per cent.

Figure 7 shows that the dispersion of self-employed rates is lower due to simpler tax-benefit system rules, although dispersion might be underestimated, since we approximate the variety of social security rules of the vast number of social security funds managed by different self-employed categories. 


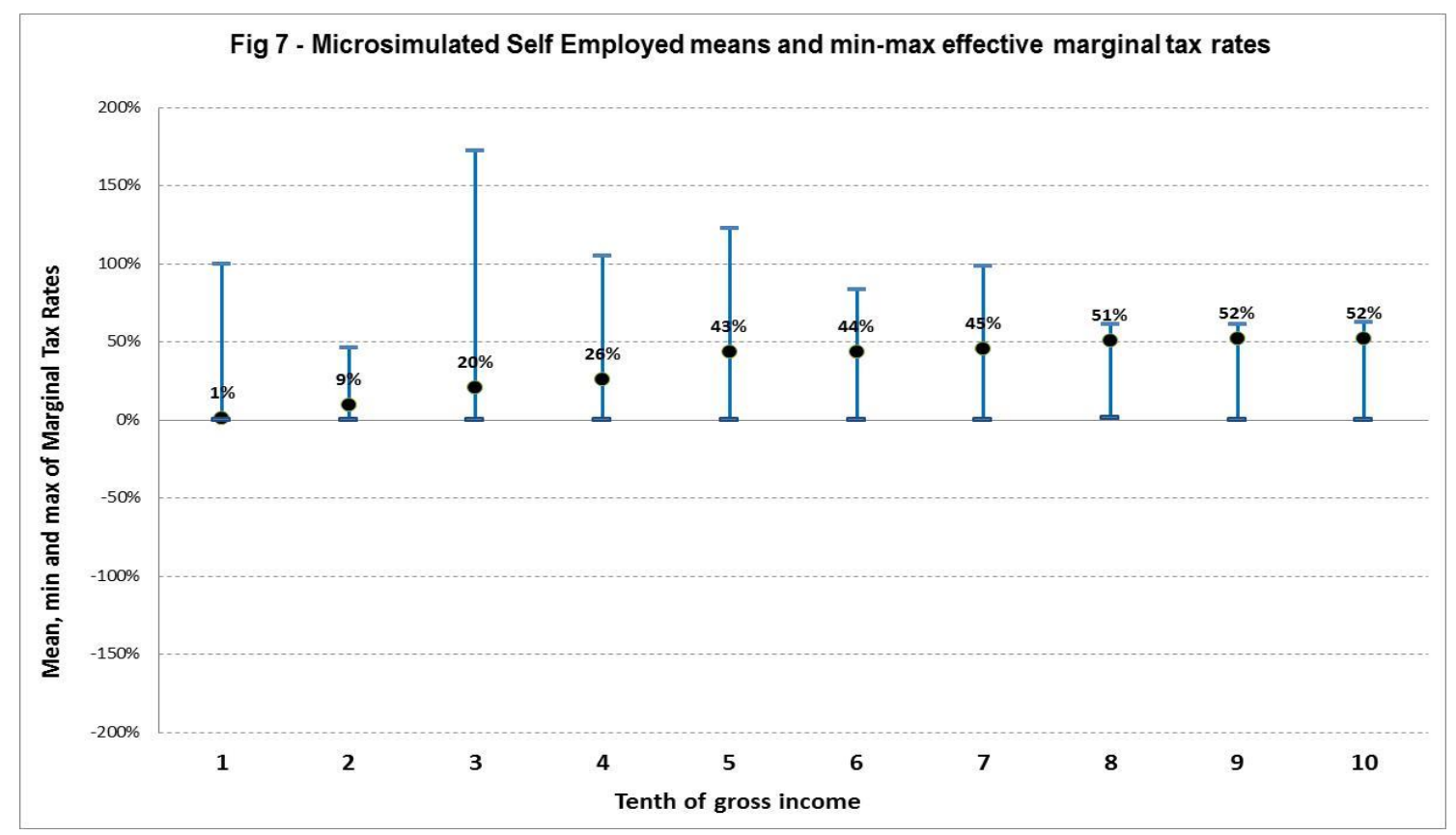

\subsection{Income and EMTR correlations}

To show better the relationship between gross income levels and EMTRs, as a consequence of the complex Italian tax-benefit system, Figure 8 shows the microsimulated frequencies of the interaction between fifths of declared gross income and classes of EMTR.

Fig 8 - Fifths of declared gross income and classes of EMTR

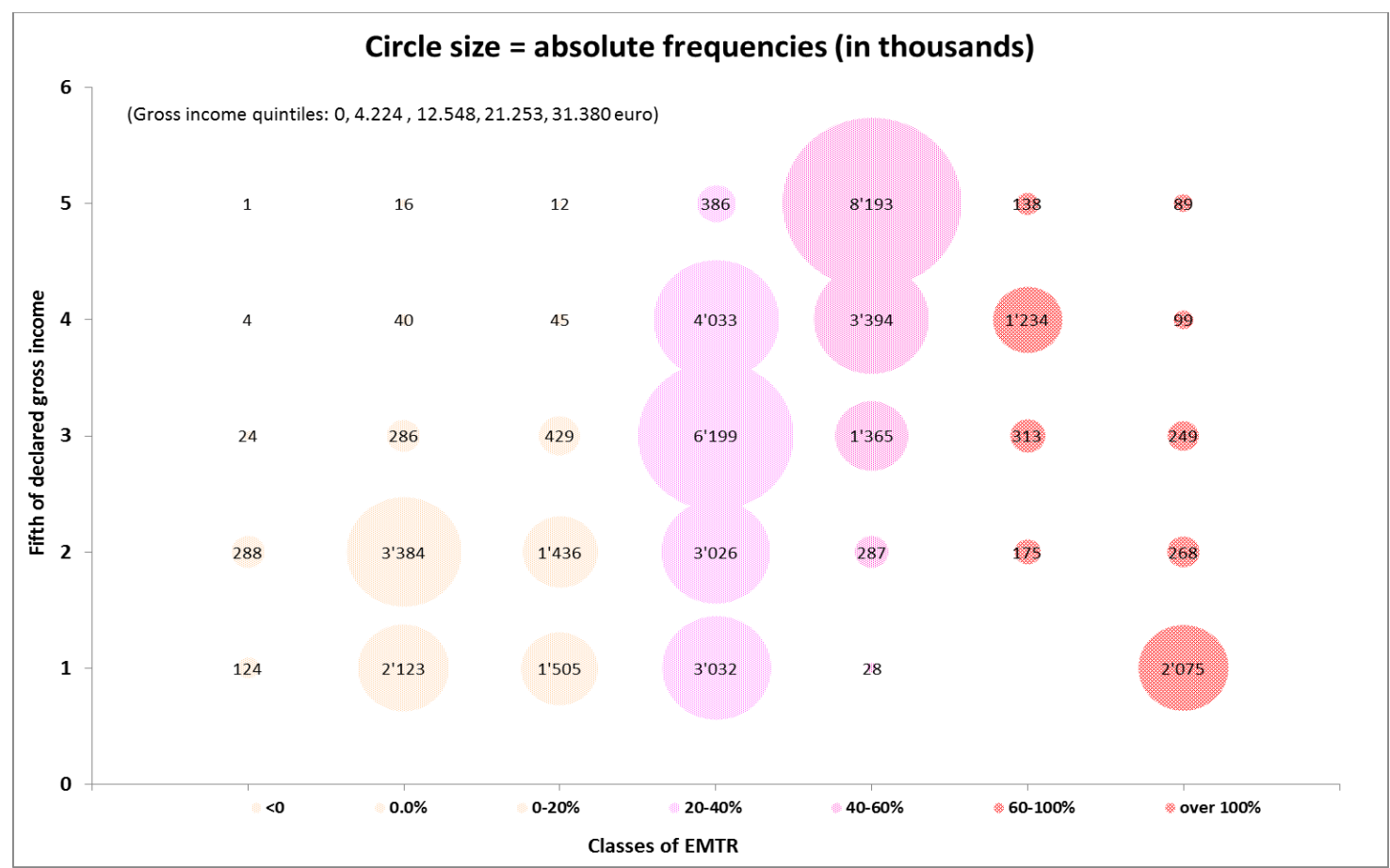


A tax-benefit system with not decreasing EMTRs as income grows should generate circles on the diagonal. By contrast, it may be observed that there are a great number of taxpayers with low income and high EMTR, or vice versa.

Low incomes belonging to the first fifth, in particular, are often associated to medium and high classes of EMTR, confirming the risk of an high EMTR when benefits get lost.

Also increasing and decreasing taxes and benefits not based on equivalent actual income can generate divergences between fifths of income and classes of EMTR.

\section{Conclusions}

The Italian tax-benefit system includes a number of taxes, contributions, and transfers that significantly affect income distribution across individuals and households. This effect derives from the operation of effective average tax rates on income that result from the interaction of a large number of rules inspired from time to time by a variety of economic and social policy goals.

The extreme complexity and articulation of the system rules also generates a large variability of effective marginal tax rates across income levels, along with a large dispersion of marginal rates within each income tenth as we consider the rates distribution. These variability and dispersion are likely to exert a relevant influence on labour market participation rates and labour supply, especially for low income workers.

Despite its huge economic and social relevance, no systematic account of this aspects of the Italian tax-benefit system exists. Such an account is especially relevant as we realize that the likely effects on the effective marginal and average tax rates of the tax-benefit system are rarely taken into account when legislation is passed. At the same time, the excess burden in terms of EMTRs has probably determined a growing role for substitutive, proportional and reduced taxation.

To fill this information gap we analyse the variability of effective marginal tax rates - overall as well as for each tax and benefit category - and effective average tax rates across income levels.

These rates are generated by interacting explicit and implicit factors like statutory tax rates, income tax exemption thresholds, tax deductions, allowances with several constraints and rules, contributions ceilings and floors. 
Results show an extreme fragmentation of marginal rates: along with statutory tax rates - which could themselves be improved and simplified - exist a large number of implicit rates deriving from the effect of benefits (transfers and deductions often with opposite sign and variable size). The interaction of these two components of the system is capable of, and actually does, alter the underlying logic of the system itself.

The main findings highlight the large variability of effective marginal tax rates at low income levels, with the paradoxical results of rates around 100 percent (as personal income tax becomes positive, or when employees taxable annual income grows from 24,000 to 26,000 ); the effective average tax rates for hypothetical employees and selfemployed decrease as income increases over a small range due to the lacking application of the 80 euro monthly bonus to taxpayer with insufficient tax liability; for income levels from 28,000 euro upward the effective marginal tax rates remains substantially invariant to income changes despite the frequently announced intention by policymakers to pursue an actual progressive tax rates structure.

From a technical point of view, this effects are at least partially imputable to the policymakers tendency to increase exemption thresholds and allowances - easily noticed and appreciated by voters - without consequently reorganizing income brackets and statutory rates given the public budget constraint.

The Italian tax-benefit system seems therefore improvable at least under three distinct perspectives:

1. statutory tax rates and benefits should be reshaped so that effective marginal tax rates provide incentives for labour market participation and labour supply, mostly needed as globalization and competition by emerging markets are increasing. This reshaping would likely determine a smoother variation of marginal and average tax rates over income levels. It could be facilitated by larger tax bases obtained through tax evasion and elusion reduction;

2. lacking resources necessary to pursue more ambitious goals, the system should be rationalised and simplified by removing unnecessary complications and effective marginal tax rates hikes that derive from regulatory stratifications. This would help conjugate the two macro goals of income redistribution and labour supply incentive.

3. Family tax deductions suffer from both not reaching poorest households and being computed on individual bases. It could be useful to extend the mechanism of family 
allowance (ANF), computing explicitly the amounts on the bases of an "equivalent" income. We would also have more regular, fair, transparent and effective implicit marginal tax rates. But, all else equal, linking to a familiar income could generate slightly higher EMTR for spouse and cohabitant sons beginning to work. 


\section{References}

Aaberge R. \& Colombino U. (2008). Designing Optimal Taxes With a Microeconometric Model of Household Labour Supply. CHILD Working Paper, 6.

Aaberge R., Colombino U., \& T. Wennemo (2002). Heterogeneity in the Elasticity of Labor Supply in Italy and Some Policy Implications. CHILD Working Paper, 20.

Baldini M., Giannini S. \& Santoro A. (2017). Irpef, una riforma da fare. lavoce.info, April 2017.

Borri N., Nisticò S., Ragusa G. \& Reichlin P. (2014), Cambiare l'Irpef pensando al lavoro, lavoce.info February.

Carone G., Immervoll H., Paturot D. \& Salomäki A. (2004). Marginal Effective Tax Rates on Employment Incomes, Working Paper n.18 OECD Social, Employment and Migration, March.

Congressional Budget Office (2012a). How the Supply of Labor Responds to Changes in Fiscal Policy, Report, October.

Congressional budget Office (2012b), Effective Marginal Tax Rates for Low- and Moderate-Income Workers, Report, November.

Congressional budget Office (2015). Effective Marginal Tax Rates for Low- and Moderate-Income Workers in 2016, Report, November.

De Vincenti C. \& Paladini R. (2009). Personal income tax design for Italy: Lessons from the theory, Rivista Italiana degli Economisti, 1.

Diamond P. (1998). Optimal income taxation: An example with a u-shaped pattern of optimal marginal tax rates, American Economic Review, 88.

Di Nicola F., Mongelli G., \& Pellegrino S. (2015). The static microsimulation model of the Italian Department of Finance: Structure and first results regarding income and housing taxation, Economia Pubblica, n. 2, pp. 125-157

Di Nicola F. \& Paladini R. (2017). A tax-benefit system reform for Italy, paper presented at SIEP Conference, Catania, 22 September 2017.

Immervoll, H. (2004). Average and Marginal Effective Tax Rates Facing Workers in the EU: A MicroLevel Analysis of Levels, Distributions and Driving Factors, OECD Social, Employment and Migration Working Papers, N. 19, OECD Publishing, Paris.

Istat (2017). L'economia non osservata nei conti nazionali - Anni 2012-2015, Report Istat, 11 October.

Keane M.P. (2011). Labor Supply and Taxes: A Survey, Journal of Economic Literature, vol. 49(4), 9611075

Marino M.R. \& Zizza R. (2012). Personal Income Tax Evasion in Italy: An Estimate by Taxpayer Type, in: Tax Evasion and the Shadow Economy, Edward Elgar, Chapter 3

McAlister F., Bandyopadhyay D., Barro R., Couchman J., Gemmell N. \& Liao G. (2012). Average Marginal Income Tax Rates for New Zealand, 1907-2009, New Zealand Treasury Working Paper $12 / 04$, September.

McClelland R. \& Mok S. (2012). A Review of Recent Research on Labor Supply Elasticities, Congressional Budget Office Working Paper n. 12.

Meghir C. \& Phillips D. (2010). Labour Supply and Taxes, in T. Besley, R. Blundell, M. Gammie and J. Poterba, Dimensions of Tax Design: the Mirrlees Review, Oxford University Press, pp. 202-274

Milanovic B. (2016). Global inequality: a new approach for the age of globalization, Belknap Harvard University Press, Cambridge, Massachssets, USA, pp.212-239

Ministry of Economy and Finance (2014). Rapporto sulla realizzazione delle strategie di contrasto all'evasione fiscale, sui risultati conseguiti nel 2013 e nell'anno in corso, nonché su quelli attesi, con riferimento sia al recupero di gettito derivante da accertamento all'evasione che a quello attribuibile alla maggiore propensione all'adempimento da parte dei contribuenti, August.

Ministry of Economy and Finance (2017). Relazione sull'economia non osservata e sull'evasione fiscale e contributiva - anno 2017, June.

Piketty T., Saez E., \& Stantcheva S. (2013). Optimal taxation of top labor incomes: A tale of three elasticities, American Economic Journal: Economic Policy

Saez E. (2001). Optimal Income Taxation: An Example with a U-Shaped Pattern of Optimal Marginal Tax Rates, Review of Economics Studies, vol. 68. 